\title{
PENGEMBANGAN MODEL PEMBELAJARAN VIRTUAL UNTUK MENINGKATKAN EFEKTIVITAS PEMBELAJARAN PADA MADRASAH NEGERI DI KOTA PAREPARE
}

\author{
Hamdanah Said \\ STAIN Parepare \\ Jl. Amal Bakti No. 8 Soreang Parepare \\ Email: hamdanahsaid@gmail.com
}

\begin{abstract}
Abstrak:
Penelitian ini bertujuan untuk mendesain pembelajaran virtual untuk meningkatkan efektifitas pembelajaran pada madrasah negeri di Kota Parepare. Metode pengumpulan data yang dipergunakan dalam penelitian dan pengembangan ini adalah tes, angket, observasi, dan dokumentasi yang dianalisis secara kuantitatif dengan analisis statistik deskriptif dan inferensial. Hasil penelitian ini menunjukkan: 1)realitas pelaksanaan pembelajaran pada madrasah negeri di Kota Parepare yakni dominan menggunakan model konvensional. 2) Gambaran pengembangan model pembelajaran virtual meliputi: (a) langkah-langkah pengembangan model pembelajaran yakni: studi pendahuluan tentang potensi dan masalah, pengumpulan data, desain produk, validasi desain, uji coba pemakaian, revisi produk, dan uji coba di madrasah, (b) tahap-tahap kegiatan dalam pembelajaran yakni: orientasi dan pre test, pembelajaran secara mandiri, interaksi secara face to face di kelas, post test, dan tindak lanjut. 3) Penerapan model pembelajaran virtual dalam uji coba sangat signifikan dalam meningkatkan motivasi dan hasil belajar peserta didik. 4) Pengaruh penerapan model pembelajaran virtual terhadap efektivitas pembelajaran pada madrasah negeri di Kota Parepare sangat signifikan. Hal ini berarti bahwa efektivitas pembelajaran dapat ditingkatkan melalui penerapan model pembelajaran virtual.
\end{abstract}

\begin{abstract}
:
This Research aimed to develop Virtual learning model to increase learning effectiveness Madrasah in Parepare. The data was collected through test, questionnaire, observation, and documentation. Data processing and analysis were stated quantitative descriptive and inferencial.The result of the study indicated that; 1) The learning process at Madrasah in Parepare was the learning process dominantly used conventional method. 2) The development of Virtual learning model was described; (a) the stages of development study were as follows; identified the problem, collected the data, designed product, validation, tried out product, revised product, and experimented product in Madrasah. (b) the stages of activities were as follows; orientation and pre-test, self-studied learner, interaction by face to face, post-test, and follow-up. 3) The application of Virtual learning at Madrasah in Parepare was significant in improving student's motivation and student's achievement. 4) The influence of Virtual learning to students' learning effectiveness at Madrasah in Parepare showed significant improvement. This indicated that the students' learning effectiveness can be increased through the implementation of Virtual learning.
\end{abstract}

Kata kunci:

Pengembangan model, pembelajaran virtual, efektivitas pembelajaran 
PENDIDIKAN di Indonesia dewasa ini mengalami tantangan yang kompleks. Hal ini antara lain disebabkan oleh teknologi informasi dan komunikasi yang telah berkembang seiring dengan globalisasi yang dapat berdampak positif dan negatif pada suatu bangsa. Pendidikan sebagai bagian yang terbiasa dalam globalisasi dipandang perlu mengambil langkah-langkah terobosan yang kredibel dan akseptabel.

Upaya mengambil langkah-langkah terobosan merupakan suatu keniscayaan jika bangsa Indonesia ingin maju sejajar dengan bangsa-bangsa lain. Hal ini sejalan dengan firman Allah swt. dalam QS al-Ra'd/13: 11 tentang perubahan keadaan sesuatu kaum:

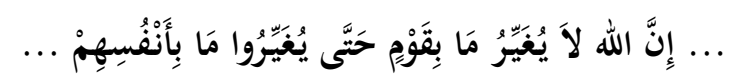

Terjemahnya:

... Sesungguhnya Allah tidak merubah keadaan sesuatu kaum sehingga mereka merubah keadaan yang ada pada diri mereka sendiri.... ${ }^{1}$

Implikasi dari ayat di atas, terutama kaitannya dengan pendidikan, bermuara pada pentingnya langkah-langkah inovasi yang tepat guna mendapatkan rida Allah swt. untuk menghantarkan tercapainya tujuan pendidikan sebagaimana yang dicitacitakan.

Di tengah tingginya tuntutan peningkatan kualitas pada semua jenjang pendidikan, keberadaan madrasah dari jenjang Madrasah Ibtidaiyah, Madrasah Tsanawiyah, dan Madrasah Aliyah, saat ini masih memprihatinkan. Permasalahan pokok dan substansial yang dihadapi madrasah adalah ketidakmampuannya mengimbangi dinamika kebutuhan masyarakat akan mutu pendidikan yang semakin tinggi serta dinamika pendidikan pada umumnya.

Semakin berkembang zaman, manusia dituntut untuk lebih baik dalam segala hal. Munculnya teknologi yang pesat saat ini membuat revolusi yang besar terhadap dunia menyebabkan semua pekerjaan terasa mudah dan murah. Perkembangan ilmu dan teknologi membawa perubahan bukan hanya pada bahan belajar (learning material), melainkan juga pada cara belajar (learning method). Sebelum teknologi komputer berkembang, bahan ajar yang pokok digunakan dalam dunia pendidikan selama beberapa abad berbentuk barang cetakan seperti buku, modul, makalah, majalah, koran, jurnal, handout, dan sebagainya. Dengan perkembangan teknologi, khususnya komputer dapat muncul alternatif sumber bahan ajar yang dapat berbentuk CD, DVD, VCD, flashdisk atau hardisk eksternal dan lain-lain.

Untuk mengimbangi perkembangan tersebut, dunia pendidikan khususnya yang berkaitan dengan proses pembelajaran di madrasah menuntut adanya variasi model pembelajaran. Variasi model pembelajaran dibutuhkan untuk mengajarkan ilmu kepada peserta didik yang semakin maju dan canggih. Dengan begitu, diharapkan dapat meningkatkan efektivitas pembelajaran dan melakukan adaptasi terhadap perkembangan di lingkungan pendidikan dan dunia kerja.

Bertitik tolak dari latar belakang masalah yang dikemukakan sebelumnya, maka yang dijadikan pokok masalah dalam penelitian ini adalah bagaimana pengem- 
bangan model pembelajaran virtual melalui eksperimen untuk meningkatkan efektivitas pembelajaran pada madrasah negeri di Kota Parepare?

Pokok permasalahan tersebut dijabarkan dalam beberapa submasalah sebagai berikut:

1. Bagaimana realitas pelaksanaan pembelajaran pada madrasah negeri di Kota Parepare?

2. Bagaimana gambaran pengembangan model pembelajaran virtual pada madrasah negeri di Kota Parepare?

3. Bagaimana efektivitas penerapan model pembelajaran virtual pada madrasah negeri di Kota Parepare?

4. Seberapa besar pengaruh penerapan model pembelajaran virtual terhadap efektivitas pembelajaran pada madrasah negeri di Kota Parepare?

\section{TINJAUAN TEORETIS}

\section{Pengembangan Model Pembelajaran}

Pengembangan model pembelajaran terdiri atas tiga kata, yakni: "pengembangan, model, dan pembelajaran". Secara etimologi, kata "pengembangan" berarti proses, cara, perbuatan mengembangkan. ${ }^{2}$ Seels dan Richey dalam Muhammad Yaumi berpendapat bahwa pengembangan adalah "the process of translating the design specifications into physical form" ${ }^{3}$ Dalam hal ini pengembangan dimaknai sebagai proses penerjemahan spesifikasi desain ke dalam bentuk fisik.

Sedangkan kata "model" berarti pola (contoh, acuan, ragam, dsb.) dari sesuatu yang akan dibuat atau dihasilkan. ${ }^{4}$ Istilah "model" dapat diartikan sebagai kerangka konseptual yang digunakan sebagai pedoman dalam melaksanakan suatu kegiatan. Dalam pengertian lain, "model" juga diartikan sebagai barang atau benda tiruan dari benda yang sesungguhnya. ${ }^{5}$ Kata model dalam penelitian ini digunakan juga untuk menunjukkan pengertian yang pertama yakni sebagai kerangka konseptual.

Pengembangan model diartikan sebagai proses desain konseptual dalam upaya peningkatan fungsi dari model yang telah ada sebelumnya melalui penambahan komponen pembelajaran yang dianggap dapat meningkatkan kualitas pencapaian tujuan. ${ }^{6}$ Pengembangan model di sini merupakan penambahan komponen desain program yang telah ada atau sedang dilaksanakan atau digunakan sehingga menjadi program yang memberi nilai tambah sehingga lebih memungkinkan pencapaian tujuan secara optimal.

Menurut Made Wena pembelajaran berarti “upaya membelajarkan peserta didik". $^{7}$ Sedangkan Abuddin Nata mengemukakan bahwa pembelajaran dapat diartikan sebagai "sebuah usaha memengaruhi emosi, intelektual, dan spiritual seseorang agar mau belajar dengan kehendaknya sendiri". ${ }^{8}$

Dari beberapa definisi tentang pembelajaran yang dikemukakan para ahli, dapat ditarik kesimpulan bahwa dalam pembelajaran, ada pemberian stimuli pada peserta didik dan interaksi edukatif sehingga mereka memiliki kesadaran dan turut serta dalam mengembangkan potensi dirinya untuk menjadi manusia yang memiliki 
sikap spiritual dan sosial, cerdas emosional, cakap, terampil, dan mandiri. Mengingat adanya berbagai interaksi tersebut, maka proses pembelajaran dapat dilakukan dengan menggunakan berbagai strategi dan model pembelajaran.

Winataputra mengemukakan bahwa model pembelajaran adalah:

Kerangka konseptual yang melukiskan prosedur yang sistematis dalam mengorganisasikan pengalaman belajar untuk mencapai tujuan belajar tertentu, dan berfungsi sebagai pedoman bagi para perancang pembelajaran dan para pengajar dalam merencanakan dan melaksanakan aktivitas pembelajaran. ${ }^{9}$

Sedangkan Joyce dalam Trianto menegaskan bahwa model pembelajaran merupakan suatu perencanaan atau suatu pola yang digunakan sebagai pedoman dalam merencanakan pembelajaran di kelas atau pembelajaran dalam tutorial dan untuk menentukan perangkat-perangkat pembelajaran termasuk di dalamnya buku-buku, film, komputer, kurikulum, dan lain-lain. ${ }^{9}$ Dengan demikian, model tersebut merupakan pola umum perilaku pembelajaran untuk mencapai tujuan pembelajaran yang diharapkan.

Sejalan dengan hal di atas, Arends dalam Trianto menyatakan "The term teaching model refers to a particular approach to instruction that includes its goals, syntax, environment, and management system." Istilah model pembelajaran di sini mengarah pada suatu pendekatan pembelajaran tertentu termasuk tujuannya, sintaksnya, lingkungannya, dan sistem pengelolaannya. ${ }^{11}$

Dari berbagai definisi di atas, dapatlah disimpulkan bahwa pengembangan model pembelajaran merupakan suatu proses desain konseptual dalam upaya peningkatan fungsi dari model yang telah ada sebelumnya, melalui penambahan komponen suatu model pembelajaran yang telah ada. Penambahan komponen suatu model dapat berupa teknologi cetak/visual, audio, audiovisual, video, film, teknologi berbasis komputer, dan teknologi terpadu yang mamadukan antara teknologi komputer, internet, dan berbagai teknologi interaktif lainnya.

Model pembelajaran yang dimaksud merupakan suatu pola atau kerangka konseptual yang melukiskan perangkat-perangkat dan prosedur pengelolaan pembelajaran yang sistematis untuk digunakan sebagai pedoman oleh pemerhati bidang pendidikan dan guru dalam merencanakan proses pembelajaran, melaksanakan proses pembelajaran, menilai hasil pembelajaran serta mengembangkan sistem pembelajaran.

Joyce dan Weil sebagaimana dikutip oleh Udin S. Winatapura mengemukakan bahwa setiap model pembelajaran memiliki unsur-unsur sebagai berikut:

a. Sintakmatik,

b. Sistem sosial,

c. Prinsip reaksi,

d. Sistem pendukung, dan

e. Dampak instruksional dan pengiring. ${ }^{12}$

Dengan demikian model pembelajaran dapat dijadikan pola pilihan oleh para guru. Guru boleh memilih model pembelajaran mana yang sesuai, efisien, dan efektif untuk mencapai tujuan pembelajaran yang dilaksanakannya. 


\section{PembelajaranVirtual}

Dalam Kamus Besar Bahasa Indonesia, kata virtual berarti (secara) nyata.13 Kata virtual dalam bahasa Arab disebut amali (عملى), fi'li (فعلى), wäqi (وقلى).14 Dalam kamus al-Munawwir, kata عملى berarti “dalam praktik", فعلى berarti “ fi'il/perbuatan", dan واقعى berarti "menurut kenyataannya/yang sebenarnya".15 Sedangkan pembelajaran berarti upaya membelajarkan peserta didik. Dengan demikian, pembelajaran virtual dapat diartikan sebagai upaya membelajarkan peserta didik secara nyata.

Sajap Maswan memaknai pembelajaran virtual (virtual learning) dengan pembelajaran maya. Maswan mengemukakan bahwa terdapat berbagai pengertian tentang pembelajaran maya dan berubah-ubah mengikuti perspektif dimana pembelajaran maya tersebut dilaksanakan. Pembelajaran maya menurut beliau sering juga dikaitkan dengan istilah-istilah dan konsep-konsep lain seperti e-pembelajaran, pembelajaran secara talian (online learning), pembelajaran jarak jauh, pembelajaran berbasis web dan sebagainya. ${ }^{16}$

Model pembelajaran virtual yang dikembangkan dalam penelitian ini merupakan pengembangan dari pembelajaran berbasis komputer dan sekolah virtual, yakni pembelajaran melalui media komputer berupa program pembelajaran yang menyajikan materi-materi pelajaran sesuai dengan kurikulum yang berlaku pada madrasah. Program pembelajaran ini dapat meliputi aspek penyajian materi pelajaran, praktik dan latihan, tutorial, simulasi, dan permainan, yang dapat dipelajari oleh peserta didik kapan dan dimana saja tanpa menggunakan jaringan internet.

Selanjutnya, I.N. Thut dan Don Adams mengemukakan bahwa harus diciptakan sebuah teknologi pendidikan yang dirancang untuk negara yang sedang berkembang. ${ }^{17}$ Teknologi pendidikan yang efisien akan sangat membantu dampak pelipatgandaan dan penyebaran pengetahuan. Guru perlu mengubah ruang kelas tradisional menjadi apa yang oleh Carl Rogers disebut "fasilitator belajar" atau apa yang oleh Keller dinamakan "insinyur pendidikan" atau "manajer kontingensi". ${ }^{18}$

Menurut Hamzah B. Uno dan Nina Lamatenggo, globalisasi telah memicu kecenderungan pergeseran dalam dunia pendidikan, dari pendidikan tatap muka yang konvensional ke arah pendidikan yang lebih terbuka. Mereka memberi contoh tentang adanya proyek "flekxible learning" di Prancis. ${ }^{19}$ Kini kita telah berada pada era komputer yang dapat digunakan untuk lebih menguatkan pembelajaran konvensional melalui produksi media pembelajaran atau buku komputer dengan model pembelajaran virtual. Dengan memanfaatkan komputer sebagai multimedia ${ }^{20}$ pembelajaran, maka tugas guru akan menjadi ringan dan guru bukan lagi sebagai satusatunya sumber informasi dalam pembelajaran.

Guru sering dihadapkan pada tuntutan mengejar penyelesaian isi silabus dalam kurun waktu tertentu sehingga tidak peduli apakah tiap-tiap peserta didik telah mencapai kompetensi yang diharapkan dalam satu sesi pembelajaran atau belum seluruhnya. Jika hal ini terjadi, maka yang korban adalah peserta didik yang lambat belajarnya. 
Sehubungan dengan hal ini, Sayling Wen menyatakan bahwa:

Saya tidak memandang sebuah kelas sebagai terdiri dari siswa-siswa yang pandai dan siswa-siswa yang bodoh, atau siswa-siswa dengan hasil baik dan siswa-siswa dengan hasil buruk. Hanya ada siswa yang lebih cepat dan lebih lamban. Ada yang membutuhkan enam bulan untuk menguasai yang dikuasai temannya dalam waktu tiga bulan. ${ }^{21}$

Melalui model pembelajaran virtual, peserta didik dapat mengulang-ulang aktivitas belajarnya sesuai kemajuan masing-masing. Setelah seorang peserta didik menyelesaikan suatu pelajaran, ia dapat mengerjakan tes sederhana yang ada dalam program yang diadministrasikannya sendiri. Kalau ia berhasil menjawab dengan benar, ia dapat melanjutkan ke pembelajaran berikutnya. Mereka yang hasilnya baik dapat melaju lebih cepat dan yang lebih lamban dapat diberikan waktu lebih. Dengan demikian, semua peserta didik dapat sampai di garis akhirnya, yakni semua peserta didik menguasai kompetensi yang harus dicapainya.

Pembelajaran virtual memanfaatkan komputer sebagai multimedia pembelajaran dengan menyuguhkan menu pembelajaran yang bervariasi antara lain: (1) narasi, (2) dril atau praktik , (3) tutorial, (4) simulasi, dan (5) game (termasuk animasi dan video). Dengan model yang bervariasi serta presentasi materi dengan menggunakan kata-kata (verbal form) sekaligus gambar (pictorial form), peserta didik dapat memanfaatkan kapasitas manusia sepenuhnya untuk memproses informasi. Hal ini sejalan dengan firman Allah swt. dalam QS al-Nahl: 16/78 tentang komponen pada diri manusia yang harus digunakan dalam proses pembelajaran:

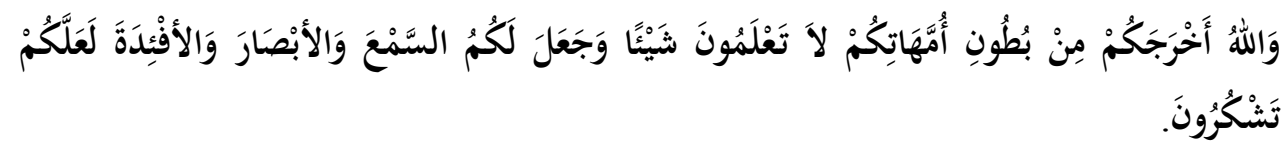

Terjemahnya:

... dan Allah mengeluarkan kamu dari perut ibumu dalam keadaan tidak mengetahui sesuatupun, dan Dia memberi kamu pendengaran, penglihatan dan hati, agar kamu bersyukur. ${ }^{22}$

Ayat di atas mengisyaratkan adanya tiga komponen yang terlibat dalam proses pembelajaran, yaitu; al-sam'a, al-bashar dan fu'ad. Secara leksikal, kata al-sam'a berarti telinga yang fungsinya menangkap suara atau pembicaraan, dan selainnya. Penyebutan al-sam'a dalam Alquran seringkali dihubungkan dengan penglihatan dan hati, yang menunjukkan adanya saling melengkapi antara berbagai alat itu dalam kegiatan pembelajaran. Namun, banyak manusia yang tidak memanfaatkannya dengan baik.

\section{Teori Belajar yang Mendukung Model Pembelajaran Virtual}

Teori belajar pada dasarnya merupakan penjelasan mengenai bagaimana terjadinya belajar atau bagaimana informasi diproses di dalam pikiran peserta didik. Teori-teori belajar yang melandasi model pembelajaran virtual antara lain sebagai berikut: 


\section{Teori Belajar Konstruktivisme}

Teori pembelajaran konstruktivis (constructivist theories of learning) ini menyatakan bahwa siswa harus menemukan sendiri dan mentransformasikan informasi kompleks, mengecek informasi baru dengan aturan-aturan lama dan merevisinya apabila aturan-aturan itu tidak lagi sesuai. ${ }^{23}$ Menurut teori ini, satu prinsip yang paling penting dalam psikologi pendidikan adalah bahwa guru tidak hanya sekedar memberikan pengetahuan kepada peserta didik. Peserta didik harus membangun sendiri pengetahuan dalam benaknya. ${ }^{24}$ Berkaitan dengan hal ini, Nur sebagaimana dikutip oleh Trianto mengemukakan bahwa guru dapat memberi siswa anak tangga yang membawa siswa ke pemahaman yang lebih tinggi, dengan catatan peserta didik sendiri yang harus memanjat anak tangga tersebut. ${ }^{25}$

Bertolak dari kaidah-kaidah dan anggapan yang dianut teori belajar konstruktivisme di atas, maka dipilihlah dan diterapkan beberapa sistem dalam implementasi model pembelajaran virtual, di antaranya melalui pembelajaran individual (selfinstruction); yang diwujudkan dalam bentuk belajar mandiri (self-learning) dengan menggunakan program pembelajaran virtual berbasis komputer. Dengan demikian peserta didik yang berkemampuan tinggi dapat lebih cepat menuntaskan pembelajarannya, sedangkan peserta didik berkemampuan rendah atau yang lambat belajarnya dapat mengulangi pembelajaran sampai mencapai kriteria ketuntasan tanpa terikat dengan waktu dan tempat.

\section{Teori Belajar Kognitif}

Tokoh teori belajar kognitif adalah Jerome Bruner dan Jean Piaget. Teorinya didasarkan pada asumsi bahwa:

(1) individu mempunyai kemampuan memroses informasi; (2) kemampuan memroses informasi tergantung kepada faktor kognitif yang perkembangannya berlangsung secara bertahap sejalan dengan tahapan usianya; (3) belajar adalah proses internal yang kompleks berupa pemrosesan informasi; (4) hasil belajar adalah berupa perubahan struktur kognitif; (5) cara belajar pada anak-anak dan orang dewasa berbeda sesuai tahap perkembangannya. ${ }^{26}$

Pembelajaran berbasis komputer sangat dipengaruhi oleh teori belajar kognitif model pemrosesan informasi (information processing model), yang mulai berkembang pada tahun 60 dan 70-an, yang dipelopori oleh Robert Gagne. Asumsinya adalah "pembelajaran merupakan faktor yang sangat penting dalam perkembangan".27 Model ini menampilkan konseptualisasi dari sistem memori pada manusia yang mirip dengan sistem memori pada komputer. Model pemrosesan informasi ini menjelaskan pemrosesan, penyimpanan, dan pemanggilan kembali pengetahuan dari otak. Peristiwa-peristiwa mental diuraikan sebagai transformasi informasi dari input (stimulus) ke output (respons). ${ }^{28}$

Mencermati teori belajar kognitif model pemrosesan informasi di atas yang menampilkan konseptualisasi dari sistem memori pada manusia yang mirip dengan sistem memori pada komputer, maka sistem memori dalam model pembelajaran vir- 
tual yang dikembangkan dengan menggunakan program pembelajaran berbasis komputer mirip pula dengan sistem memori pada manusia.

\title{
Efektivitas Pembelajaran
}

Dalam kehidupan sehari-hari di lembaga pendidikan, termasuk madrasah, masalah "efektivitas pembelajaran" seringkali menjadi sorotan, terutama menjelang dan setelah pelaksanaan ujian akhir semester dan ujian nasional. Sering kali terdengar ungkapan bahwa saya tidak mau menyekolahkan anak saya di madrasah tersebut karena tidak efektif pembelajarannya, banyak siswanya yang rendah nilainya dan/atau tidak lulus ujian.

Makna efektivitas secara umum menunjukkan seberapa besar tercapainya suatu tujuan yang terlebih dahulu ditentukan. Dalam Kamus Besar Bahasa Indonesia kata "efektivitas berarti keefektifan". "Keefektifan bermakna: (1) keadaan berpengaruh; hal berkesan; (2) kemanjuran, kemujaraban (tt obat); (3) keberhasilan (tt usaha, tindakan), kemangkusan". ${ }^{29}$ Hal ini sesuai dengan apa yang dikemukakan oleh Minnah El Widdah bahwa "Efektivitas mengacu kepada pencapaian target secara kualitas dan kuantitas suatu sasaran program. Makin besar persentase target suatu program yang tercapai, makin tinggi efektivitasnya". ${ }^{30}$ Dengan demikian, efektivitas ditentukan dengan melihat seberapa besar target (kuantitas, kualitas, dan waktu) telah tercapai.

Pembelajaran adalah proses membelajarkan peserta didik untuk mencapai perkembangan optimal. Hal tersebut sesuai dengan yang tertuang dalam Peraturan Menteri Pendidikan dan Kebudayaan RI No. 81A tahun 2013 bahwa:

\begin{abstract}
Secara prinsip, kegiatan pembelajaran merupakan proses pendidikan yang memberikan kesempatan kepada peserta didik untuk mengembangkan potensi mereka menjadi kemampuan yang semakin lama semakin meningkat dalam sikap, pengetahuan, dan keterampilan yang diperlukan dirinya untuk hidup dan untuk bermasyarakat, berbangsa, serta berkontribusi pada kesejahteraan hidup umat manusia.... Di dalam pembelajaran, peserta didik didorong untuk menemukan sendiri dan mentransformasikan informasi kompleks, mengecek informasi baru dengan yang sudah ada dalam ingatannya, dan melakukan pengembangan menjadi informasi atau kemampuan yang sesuai dengan lingkungan dan jaman tempat dan waktu ia hidup. ${ }^{31}$
\end{abstract}

Berdasarkan apa yang telah dikemukakan di atas dapat ditarik kesimpulan bahwa efektivitas pembelajaran merupakan pencapaian target pembelajaran secara kualitas dan kuantitas secara optimal sesuai sasaran program yang telah ditetapkan, yakni perkembangan optimal potensi peserta didik pada aspek sikap, pengetahuan, dan keterampilan. Pembelajaran efektif bukan membuat peserta didik pusing, tetapi bagaimana tujuan pembelajaran dapat tercapai dengan mudah dan menyenangkan. ${ }^{32}$ Pembelajaran yang efektif menurut Yusufhadi Miarso adalah "Yang menghasilkan belajar yang bermanfaat dan bertujuan bagi para mahasiswa/peserta didik, melalui pemakaian prosedur yang tepat". 33 
Efektivitas pembelajaran tidak serta merta tercapai dengan sendirinya, tetapi berhubungan pula dengan kondisi peserta didik. Menurut Nasution sebagaimana dikutip oleh Fadli bahwa untuk belajar sesuatu seseorang memerlukan empat kondisi yang fundamental, yaitu: (1) harus menginginkan sesuatu; (2) memperhatikan sesuatu; (3) melakukan sesuatu; dan (4) harus memperoleh sesuatu. ${ }^{34}$

Tony Stockwell, ahli psikologi pendidikan kelahiran Inggris dalam Gordon Dryden juga menyatakan "Sekarang kita tahu bahwa untuk mempelajari sesuatu dengan cepat dan efektif, kita harus melihat, mendengar, dan merasakannya." 33 Mencermati pendapat ini, maka untuk mencapai efektivitas pembelajaran diperlukan model pembelajaran yang dapat menampilkan desain instruksional yang baik, sumber belajar yang beragam, menggunakan multimedia serta strategi dan metode pembelajaran yang berpariasi. Jika faktor-faktor tersebut mendapat perhatian para penanggungjawab pembelajaran, maka pembelajaran akan menjadi efektif. Sebaliknya, jika faktor tersebut terabaikan, maka hasil belajar dapat mengecewakan.

\section{Pengukuran Keefektifan Pembelajaran}

Keefektifan pembelajaran merupakan aspek yang amat penting mendapatkan perhatian setiap guru. Salah satu indikator guru profesional adalah memiliki kemampuan melakukan pengukuran terhadap keefektifan pembelajaran dengan baik dan benar. Hal ini penting dilakukan untuk mengetahui pencapaian tujuan pembelajaran.

Berkaitan dengan pengukuran keefektifan pembelajaran ini, Reigeluth dan Merrill dalam Nyoman Sudana dan Yusuf Hadi Miarso mengemukakan bahwa "Pengukuran keefektifan pembelajaran harus selalu dikaitkan dengan pencapaian tujuan pembelajaran". ${ }^{36}$ Menurut Slavin, indikator suatu pembelajaran dikatakan efektif dapat terlihat dari: (a) Kualitas pembelajaran (Quality of instruction). Kualitas pembelajaran dapat terlihat dari ketercapaian tujuan instruksional pembelajaran yang terdapat pada indikator pembelajaran dan kemampuan anak setelah penerapan pembelajaran, (b) Kesesuaian tingkat pembelajaran (Appropriate levels of instruction). Hal ini terlihat pada indikator ketercapaian yang terdapat pada silabus, program tahunan atau program semester yang telah direncanakan oleh guru, (c) Motivasi dalam pembelajaran (Incentive of instruction). Cara guru memberikan motivasi yang dapat terlihat dari respons dan minat siswa saat berlangsungnya pembelajaran, dan (d) Waktu (time). Keefisienan waktu dan pengaturan waktu yang telah dilakukan oleh guru dalam proses pembelajaran. ${ }^{37}$

Sejalan dengan pendapat tersebut, Muhammad Yaumi menegaskan bahwa efektivitas selalu dinilai dari apa yang telah diperoleh siswa dalam pembelajaran, apakah telah memenuhi tujuan yang diinginkan atau belum. Ketercapaian tujuan menurutnya menjadi indikator utama dalam menentukan tingkat efektivitas suatu pelaksanaan pembelajaran. ${ }^{38}$

Dari uraian di atas dapat ditarik kesimpulan bahwa efektivitas pembelajaran adalah adanya pengaruh atau hasil guna berupa pengembangan potensi serta peningkatan sikap spiritual dan sosial, keterampilan, dan pengetahuan peserta didik setelah pelaksanaan proses pembelajaran. Dengan demikian, maka indikator yang di- 
gunakan dalam menilai keefektifan pembelajaran dalam penelitian ini adalah motivasi, minat, waktu, dan hasil belajar peserta didik.

\section{METODE PENELITIAN}

Jenis penelitian yang digunakan adalah penelitian dan pengembangan (reseaech and development). Uji coba model pembelajaran virtual dilakukan dengan Pre-Experimental Design One Group Pretest-Posttest Design ${ }^{39}$. Efektivitas model pembelajaran virtual yang dikembangkan diukur dengan cara membandingkan antara nilai $\mathrm{O}_{2}$ dengan nilai $\mathrm{O}_{1}$. Bila nilai $\mathrm{O}_{2}$ lebih besar daripada $\mathrm{O}_{1}$, maka model pembelajaran tersebut efektif.

Populasi dalam penelitian ini adalah seluruh peserta didik madrasah negeri di Kota Parepare pada tahun pelajaran 2012/2013 yang berjumlah 757 orang. Populasi yang terjangkau dalam penelitian ini adalah peserta didik kelas VIII MTsN dan kelas XI MAN. Karakteristik populasi relatif homogen, yakni mengikuti proses pembelajaran yang dominan menggunakan metode pembelajaran yang konvensional (Lecturer Centered Learning) dan telah memiliki kemampuan mengoperasikan komputer.

Penentuan sampel dari kelas paralel dilakukan dengan teknik random sampling melalui undian, ${ }^{40}$ sehingga anggota sampel yang terpilih adalah kelas VIII2 dan VIII4 pada MTsN, kelas XI IPA pada MAN 1, dan kelas XI IPA1 dan IPS1 pada MAN 2 Parepare. Sampel yang terpilih sebanyak 96 orang atau 13\% dari total populasi.

Langkah-langkah yang dilakukan dalam penelitian ini merujuk pada pendapat Sugiyono yang menyatakan bahwa langkah-langkah penggunaan metode penelitian dan pengembangan meliputi sepuluh langkah, yaitu: 1) potensi dan masalah; 2) pengumpulan data; 3) desain produk; 4) validasi desain; 5) uji coba pemakaian; 6) revisi produk; 7) uji coba produk; 8) revisi desain; 9) revisi produk; 10) produksi massal. ${ }^{41}$

Dalam Uji validitas butir soal digunakan program ANATEST. Selanjutnya, validasi produk terdiri atas: 1) validasi ahli komunikasi pendidikan; 2) ahli materi pembelajaran; dan 3) ahli media/teknologi pembelajaran, diperoleh berupa masukan dari ahli tersebut yang dihimpun dari angket. Data yang diperoleh dari penelitian diolah dan dianalisis dengan menggunakan analisis statistik deskriptif dan inferensial.

\section{HASIL PENELITIAN DAN PEMBAHASAN}

\section{Hasil Penelitian}

Hasil penelitian tentang realitas pelaksanaan pembelajaran pada madrasah negeri di Kota Parepare, menunjukkan bahwa sebelum pelaksanaan pembelajaran di kelas, terlebih dahulu para guru menyusun silabus, program tahunan, program semester, rincian pekan efektif, rencana pelaksanaan pembelajaran (RPP), dan menetapkan kriteria ketuntasan minimal serta menyiapkan media dan sumber belajar. Namun, masih terdapat kesenjangan antara tuntutan kurikulum dengan model pem- 
belajaran yang ditampilkan oleh guru dalam proses pembelajaran. Pada umumnya guru dominan melaksanakan pembelajaran dengan model konvensional.

Dalam hal penggunaan media pembelajaran, terlihat masih belum dapat membantu mengoptimalkan efektivitas pembelajaran. Kondisi yang demikian memberi dampak pada hasil belajar, di mana hasil pre tes menunjukkan bahwa hanya terdapat 26 orang $(27.08 \%)$ responden pada madrasah negeri di Kota Parepare yang menjadi sampel dalam penelitian ini memperoleh skor pre tes 50 ke atas (cukup baik, baik, dan sangat baik), sisanya $70.83 \%$ memperoleh nilai pre tes di bawah nilai 50 (kategori kurang baik). Sedangkan, hanya 1 orang (1.04\%) responden yang memperoleh hasil post tes di bawah nilai 50 (kategori kurang baik). Untuk itu, model pembelajaran virtual dapat dijadikan sebagai salah satu alternatif solusi untuk mengatasi masalah tersebut dan diharapkan dapat meningkatkan efektivitas pembelajaran di madrasah.

Pengembangan model pembelajaran virtual pada madrasah negeri di Kota Parepare dilakukan dengan merujuk pada pendapat Joyce dan Weil yang menegaskan bahwa setiap model pembelajaran memiliki unsur-unsur: asumsi dan tujuan, sintakmatik, sistem sosial, prinsip reaksi, sistem pendukung, dan dampak instruksional serta pengiring. Model pembelajaran virtual yang dikembangkan ini memiliki pula unsur-unsur tersebut.

Penelitian ini merujuk pula pada pendapat Sugiyono yang menyatakan bahwa langkah-langkah penggunaan metode penelitian dan pengembangan meliputi sepuluh langkah, yaitu: 1) potensi dan masalah; 2) pengumpulan data; 3) desain produk; 4) validasi desain; 5) uji coba pemakaian; 6) revisi produk; 7) ujicoba produk; 8) revisi desain; 9) revisi produk; dan 10) produksi massal.

Model pembelajaran virtual ini memiliki empat tahap kegiatan. Tahap pertama, orientasi dan pre tes. Tahap kedua, pembelajaran secara mandiri. Tahap ketiga, interaksi secara face to face di kelas. Tahap keempat, post tes dan tindak lanjut.

Hipotesis yang diajukan dalam penelitian ini adalah penerapan model pembelajaran virtual berpengaruh secara signifikan terhadap efektivitas pembelajaran pada madrasah negeri di Kota Parepare. Pengujian hipotesis dilakukan dengan uji perbedaan dengan menggunakan uji t. Berikut ini dikemukakan rangkuman hasil uji $t$ sebagaimana dapat dilihat pada tabel berikut ini:

Tabel Rangkuman Hasil Uji-t Perolehan Skor Pretes Gabungan Post Tes

\begin{tabular}{|c|c|c|c|c|c|c|}
\hline Variabel & $\mathbf{N}$ & Mean & Std. & Nilai-t & Df & Sig. \\
\hline Tes 1 (pre) & \multirow[t]{2}{*}{15} & 30.36 & 11.629 & \multirow[t]{2}{*}{12.616} & \multirow[t]{2}{*}{14} & \multirow[t]{2}{*}{, 000 } \\
\hline (pos) & & 78.67 & 8.338 & & & \\
\hline Tes 2 (pre) & \multirow[t]{2}{*}{15} & 26.67 & 14.960 & \multirow[t]{2}{*}{12.076} & \multirow[t]{2}{*}{14} & \multirow[t]{2}{*}{, 000 } \\
\hline (pos) & & 76.67 & 8.165 & & & \\
\hline Tes 3 (pre) & \multirow[t]{2}{*}{18} & 32.22 & 15.168 & \multirow[t]{2}{*}{11.800} & \multirow[t]{2}{*}{17} & \multirow[t]{2}{*}{, 000 } \\
\hline (pos) & & 77.22 & 6.691 & & & \\
\hline
\end{tabular}




\begin{tabular}{|r|l|r|r|r|r|r|}
\hline Tes 4 (pre) & 21 & 39.05 & 13.381 & 17.287 & 20 &, 000 \\
\hline (pos) & & 88.10 & 5.118 & & & \\
\hline Tes 5 (pre) & 18 & 43.89 & 16.852 & 9.897 & 17 &, 000 \\
(pos) & & 80.56 & 8.726 & & & \\
\hline Tes 6 (pre) & 42 & 54.29 & 19.272 & 8.190 & 41 &, 000 \\
(pos) & & 78.33 & 12.281 & & & \\
\hline Tes 7 (pre) & 42 & 29.29 & 14.880 & 14.323 & 41 &, 000 \\
(pos) & & 73.81 & 16.521 & & & \\
\hline Tes 8 (pre) & 21 & 32.38 & 19.211 & 12.938 & 20 &, 000 \\
(pos) & & 87.14 & 5.606 & & & \\
\hline
\end{tabular}

Hipotesis statistik:

$\mathrm{H}_{\mathrm{o}}: \mu_{\mathrm{x}}=\mu_{\mathrm{Y}}$

$\mathrm{H}_{1}: \mu_{\mathrm{x}} \neq \mu_{Y}$

Pada tabel hasil uji $\mathrm{t}$ di atas diperoleh $t_{\text {hitung }}$ masing-masing sebesar 12.616, $12.076,11.800,17.287,9.897,8.190,14.323$, dan 12.938 dengan masing-masing signifikansi 0,000. Karena sig $=0,000<0,05$, maka hipotesis yang diajukan diterima, yakni terdapat perbedaan yang signifikan antara hasil belajar sebelum dan sesudah perlakuan, dengan mean (rata-rata) pre tes pada delapan kali uji coba, lebih kecil dari mean pos tes. Artinya, penerapan model pembelajaran virtual yang diberikan memberikan efek atau pengaruh yang signifikan terhadap hasil belajar peserta didik.

Pelaksanaan uji coba menunjukkan bahwa peserta didik pada kelas eksperimen yang menggunakan model pembelajaran virtual tampak sangat termotivasi, aktif, senang, dan betah dalam proses pembelajaran. Hal ini dapat dilihat pada setiap uji coba yang menunjukkan terjadinya peningkatan hasil pada semua kelompok eksperimen. Ketermotivasian responden rata-rata $90,62 \%$, hasil pre tes menunjukkan hanya terdapat 14 orang $(14,58 \%)$ responden memperoleh nilai kategori baik dan sangat baik (70-100), sedangkan hasil post tes sebanyak 81 orang $(84,38 \%)$ kategori baik dan sangat baik. Sisanya termasuk kategori cukup baik dan kurang baik.

Model Pembelajaran virtual memiliki karakteristik antara lain: (1) mengembangkan kreativitas dan kemandirian peserta didik dalam proses pembelajaran; (2) adanya pengakuan atas perbedaan individual peserta didik yakni sesuai dengan karakteristik peserta didik yang heterogen; (3) pembelajaran yang menerapkan prinsip bahwa siapa saja adalah guru, siapa saja adalah peserta didik, dan di mana saja adalah kelas; (4) pemanfaatan teknologi komputer untuk meningkatkan efisiensi dan efektivitas pembelajaran; dan (5) pembelajaran tidak terikat oleh waktu dan dapat berlangsung di rumah, di sekolah, dan di masyarakat; dan (6) pembelajaran dapat berlangsung tanpa jaringan internet.

\section{Pembahasan}

Dari uraian di atas, ditemukan bahwa terdapat perbedaan yang signifikan antara hasil belajar sebelum dan sesudah perlakuan dengan mean pre tes lebih kecil dari 
mean pos tes. Artinya, penerapan model pembelajaran virtual yang diberikan memberikan pengaruh signifikan terhadap efektivitas pembelajaran. Hal ini berarti bahwa efektivitas pembelajaran dapat ditingkatkan melalui penerapan model pembelajaran virtual.

Jika peningkatan dimaknai sebagai perbedaan yang signifikan antara nilai pre tes dan pos tes, maka uji coba pengembangan model pembelajaran virtual memperlihatkan keberhasilan (efektivitas) yang sangat berarti dalam mengoptimalkan peningkatan motivasi, lama belajar, dan hasil belajar peserta didik. Hal ini dapat dilihat pada setiap uji coba yang menunjukkan terjadinya peningkatan hasil pada semua kelompok eksperimen. Dengan demikian, jelas bahwa tingkat keberhasilan eksperimen penerapan model pembelajaran virtual dalam meningkatkan efektivitas pembelajaran pada madrasah negeri di Kota Parepare berada pada kategori tinggi. Hal ini terlihat dari tingginya motivasi belajar peserta didik dan nilai rata-rata pos tes yang jauh lebih tinggi dari nilai rata-rata pre tes. Setelah diterapkan model pembelajaran virtual, efektivitas pembelajaran meningkat.

Temuan dalam penelitian ini sejalan dengan kutipan dalam tinjauan teoretis yang mengatakan bahwa "kekuatan sejati komputer adalah sarana belajar terkontrol bagi peserta didik". Komputer sangat canggih mampu berperan, baik sebagai tutor maupun perpustakaan, menyediakan informasi dan umpan balik kepada peserta didik secara cepat. Dengan demikian, dapat dipahami bahwa peningkatan efektivitas pembelajaran berhubungan dengan beberapa faktor dan yang dapat diamati pada penelitian ini hanya faktor pengembangan dan penerapan model pembelajaran, khususnya model pembelajaran virtual pada madrasah negeri di Kota Parepare.

\section{SIMPULAN}

Realitas pelaksanaan pembelajaran pada madrasah negeri di Kota Parepare yakni dominan menggunakan model konvensional yang terlalu berorientasi teachercentered, sumber belajar berpusat pada guru.

Gambaran pengembangan model pembelajaran virtual pada madrasah negeri di Kota Parepare meliputi: (a) langkah-langkah pengembangan model pembelajaran virtual, yakni: studi pendahuluan tentang potensi dan masalah, pengumpulan data, desain produk, validasi desain, uji coba pemakaian, revisi produk, dan uji coba di madrasah, (b) tahap-tahap kegiatan dalam pembelajaran yakni: orientasi dan pre tes, pembelajaran secara mandiri, interaksi secara face to face di kelas, pos tes, dan tindak lanjut.

Efektivitas penerapan model pembelajaran virtual pada madrasah negeri di Kota Parepare telah diujicobakan melalui eksperimen dan memperlihatkan keberhasilan yang sangat signifikan dalam meningkatkan motivasi dan hasil belajar peserta didik.

Pengaruh penerapan model pembelajaran virtual terhadap efektivitas pembelajaran pada madrasah negeri di Kota Parepare sangat signifikan. Hasil uji t menyimpulkan bahwa terdapat perbedaan yang signifikan antara hasil belajar sebelum dan sesudah perlakuan dengan mean pre tes lebih kecil dari mean pos tes dengan signi- 
fikansi 0,00<0,05. Hal ini berarti bahwa efektivitas pembelajaran dapat ditingkatkan melalui penerapan model pembelajaran virtual.

\section{CATATAN AKHIR:}

1. Departemen Agama RI, Al-Qur'an dan Terjemahnya, Semarang: PT Karya Toha Putra, 2002, h. 337-338.

2. Departemen Pendidikan Nasional, Kamus Besar Bahasa Indonesia, Edisi Ketiga, Jakarta: Balai Pustaka, 2002, h. 414.

3. Muhammad Yaumi, Prinsip-prinsip Desain Pembelajaran, Cet. ke-2, Jakarta: Kencana Prenadamedia Group, 2013, h. 6.

4. Departemen Pendidikan dan kebudayaan, op. cit. h. 589.

5. Udin S. Winataputra, Model-model Pembelajaran Inovatif, Edisi Revisi, Cet. Ke- 5, Jakarta: PAU-PPAI, Direktorat Jenderal Pendidikan Tinggi Departemen Pendidikan Nasional, 2005, h. 3.

6. Awandi Nopyan Sugiarta (2007) Repository.upl h. 11.

7. Made Wena, Strategi Pembelajaran Inovatif Kontemporer; Suatu Tinjauan Konseptual Operasional, Jakarta: PT. Bumi Aksara, 2009, h. 2.

8. Abuddin Nata, Perspektif Islam Tentang Strategi Pembelajaran, Jakarta: Kencana, 2009, h. 85.

9. Udin S. Winataputra, op. cit., h. 3.

10. Trianto, Model-model Pembelajaran Inovatif Berorientasi Konstruktivistik; Konsep, Landasan Teoritis-Praktis dan Implementasinya. Cet. I, Jakarta: Prestasi Pustaka, 2011, h. 5.

11. Ibid., h. 5-6.

12. Udin S. Winataputra, op. cit., h. 8.

13. Departemen Pendidikan Nasional, op. cit., h. 1262.

14. Munir Ba'albaki, Al-Mawrid a Modern English-Arabic Dictionary, Bairut-Lebanon: Dar El-Ilm Lil-Malayen, 2002) h. 1032.

15. Ahmad Warson Munawwir, Kamus Al-Munawwir Arab-Indonesia Terlengkap, Edisi Kedua, Cetakan ke-14, Yogyakarta: Pustaka Progressif, 1997, h. 1064.

16. Sajap Maswan, "Pembelajaran Maya (Virtual Learning) dan Pembangunan Komuniti", http://www.sajadstudio.info/artikel/virtual komuniti.pdf, h. 9. (diakses, 30-12-2012).

17. Hergenhahn Matthew, H. Olson, Theories of Learning (Teori Belajar), dialihbahasakan oleh Tri Wibowo B.S., Edisi ketujuh, Jakarta: Kencana Prenada Media Group, 2009, h. 132.

18. I.N. Thut dan Don Adams, Educational Patterns in Contemporary Societies, Penerjemah SPA Teamwork, Judul: Pola-pola Pendidikan dalam Masyarakat Kontemporer, cet. I; Yogyakarta: Pustaka Pelajar, 2005, h. 540.

19. Hamzah B. Uno dan Nina Lamatenggo, Teori Kinerja dan Pengukurannya, cet. I, Jakarta: PT Bumi Aksara, 2012, h. 21.

20. Rusman, Model-Model Pembelajaran; Mengembangkan Profesionalisme Guru, Jakarta: RajaGrafindo Persada, 2011, h. 135.

21. Lihat Richard E. Mayer, Multimedia Learning Prinsip-prinsip dan Aplikasi, Yogyakarta: Pustaka Pelajar, 2009, h. 7.

22. Lihat Sayling Wen, Future of Education (Masa Depan Pendidikan), Alih bahasa: Arvin Saputra, Batam: Lucky Publisher, 2003, h. 47.

23. Departemen Agama RI, op. cit., h. 375.

24. Trianto, Model-model Pembelajaran Inovatif Berorientasi Konstruktivistik, Jakarta: Prestasi Pustaka Publisher, 2007, h. 13.

25. Ibid., h.14. 
26. Tatang Syarifuddin, Landasan Pendidikan, cet. I. Jakarta: Dirjen Pendidikan Islam Depag RI, 2009, h. 112.

27. Rusman, op. cit., h. 139.

28. Trianto, op. cit., h. 19.

29. Departemen Pendidikan Nasional, op. cit., h. 352.

30. Minnah El Widdah, dkk., Kepemimpinan Berbasis Nilai dan Pengembangan Mutu Madrasah, Bandung: Alfabeta, 2012, h. 55.

31. Republik Indonesia, "Peraturan Menteri Pendidikan dan Kebudayaan RI No. 81A tahun 2013 tentang Implementasi Kurikulum, Pedoman Umum Pembelajaran", h. 4.

32. Veithzal Rivai, dan Sylviana Murni. Education Management Analisis Teori dan Praktik. Jakarta: Rajawali Pers, PT Rajagrafindo Persada, 2009, h. 731.

33. Yusufhadi Miarso, Menyemai Benih Teknologi Pendidikan, Jakarta: Kencana, 2004, h. 536.

34. Nasution dalam Fadli, "Desain Model Pembelajaran Virtual pada Pelajaran Matematika", fadlibae.wordpress.com/2011/12/04/desai, (30 Desember 2012).

35. Gordon Dryden, Jeannette Vos, Revolusi Cara Belajar (The Learning Revolution), h. 299-301.

36. Nyoman Sudana Degeng dan Yusufhadi Miarso, Teknologi Pendidikan Terapan teori Kognitif dalam Desain Pembelajaran, Jakarta: Departemen Pendidikan dan Kebudayaan Dirjen Pendidikan Tinggi, 1993, h. 242.

37. http://id.shvoong.com/social-sciences/education/2256741-teori-efektivitas pembelajaran/\#ixzz1yx5MRCbm, ( 2 Juni 2012).

38. Muhammad Yaumi, Prinsip-prinsip Desain Pembelajaran, h. 4-5.

39. Sugiyono, Metode Penelitian Pendidikan (Pendekatan Kuantitatif, Kualitatif, dan R\&D), Bandung: Alfabeta, 2012, h. 110-111.

40. Muhammad Arif Tiro dan Nur Hidayah, Metode Penelitian Sosial Pendekatan Survei, Makassar: Andira Publisher, 2011, h. 162.

41. Sugiyono, op. cit., h. 409.

\section{DAFTAR PUSTAKA}

al-Qur'an al-Karim

Ba'albaki, Munir. Al- Mawrid a Modern English-Arabic Dictionary. Bairut-Lebanon: Dar El-Ilm Lil-Malayen, 2002

Degeng, Nyoman Sudana dan Yusufhadi Miarso. Buku Pegangan Teknologi Pendidikan: Terapan Teori Kognitif dalam Desain Pembelajaran. Jakarta: Departemen Pendidikan dan Kebudayaan, 1993.

Departemen Agama RI. Al-Qur'an Al-Karim dan Terjemahnya, diterjemahkan oleh Yayasan Penyelenggara Penerjemah Al-Qur'an. Semarang: PT. Karya Toha Putra, 2002.

Departemen Pendidikan Nasional. Kamus Besar Bahasa Indonesia. Edisi Ketiga, Jakarta: Balai Pustaka, 2002.

Dryden, Gordon \& Jeannette Vos. Revolusi Cara Belajar (The Learning Revolution). Selandia Baru: The Learning Web, 1999.

Fadli. "Desain Model Pembelajaran Virtual pada Pelajaran Matematika". fadlibae.wordpress. com/2011/12/04.

http://id.shvoong.com/social-sciences/education/2256741-teori-efektivitaspembelajaran/ \#ixzz1yx5MRCbm,

Maswan, Sajap. "Pembelajaran Maya (Virtual Learning) dan Pembangunan Komuniti", http:// www.sajadstudio.info/artikel/virtual komuniti.pdf,

Matthew, Hergenhahn, H. Olson. Theories of Learning (Teori Belajar). Dialihbahasakan oleh Tri 
Wibowo B.S., Edisi ketujuh, Jakarta: Kencana Prenada Media Group, 2009.

Mayer, Richard E. Multimedia Learning, Prinsip-prinsip dan Aplikasi. Cambridge University Press, 2001. Penerjemah: Teguh Wahyu Utomo. Yogyakarta, Pustaka Pelajar, 2009.

Miarso, Yusufhadi. Menyemai Benih Teknologi Pendidikan. Jakarta: Kencana, 2004.

Munawwir, Ahmad Warson. Kamus Al-Munawwir Arab-Indonesia Terlengkap. Edisi Kedua, Cetakan ke-14, Yogyakarta: Pustaka Progressif, 1997.

Nata, Abudin. Perspektif Islam tentang Strategi Pembelajaran. Jakarta: Kencana, 2009.

Rivai, Veithzal, dan Sylviana Murni. Education Management Analisis Teori dan Praktik. Jakarta: Rajawali Pers, 2009.

Republik Indonesia. "Peraturan Menteri Pendidikan dan Kebudayaan RI No. 81A tahun 2013 tentang Implementasi Kurikulum, Pedoman Umum Pembelajaran"

Rusman. Model-model Pembelajaran: Mengembangkan Profesionalisme Guru. Jakarta: PT Raja Grafindo Persada, 2011.

Syarifuddin, Tatang. Landasan Pendidikan. Cet. I. Jakarta: Dirjen Pendidikan Islam Depag RI, 2009.

Sugiarta, Awandi Nopyan. Repository. 2007

Sugiyono. Metode Penelitian Pendidikan Pendekatan Kuantitatif, Kualitatif, dan REDD. Bandung: Alfabeta, 2012.

Thut, I.N. dan Don Adams. Educational Patterns in Contemporary Societies. Penerjemah SPA Teamwork, Judul: Pola-pola Pendidikan dalam Masyarakat Kontemporer. Cet. I; Yogyakarta: Pustaka Pelajar, 2005.

Tiro, Muhammad Arif dan Nur Hidayah. Metode Penelitian Sosial Pendekatan Survei. Makassar: Andira Publisher, 2011.

Trianto. Model-model Pembelajaran Inovatif Berorientasi Konstruktivitik; Konsep, Landasan TeoritisPraktis dan Implementasinya. Cet. I, Jakarta: Prestasi Pustaka, 2011.

Uno, Hamzah B. dan Nina Lamatenggo, Teori Kinerja dan Pengukurannya, Cet. I. Jakarta: PT. Bumi Aksara, 2012.

Wen, Sayling, Future of Education (Masa Depan Pendidikan), Alih bahasa Arvin Saputra, Lucky Publishers, 2003.

Wena, Made. Strategi Pembelajaran Inovatif Kontemporer. Jakarta: PT. Bumi Aksara, 2009.

El Widdah, Minnah, dkk. Kepemimpinan Berbasis Nilai dan Pengembangan Mutu Madrasah, Bandung: Alfabeta, 2012.

Winataputra, Udin S. Model-model Pembelajaran Inovatif, Edisi Revisi. Cet. Ke- 5, Jakarta: PAUPPAI, Direktorat Jenderal Pendidikan Tinggi Departemen Pendidikan Nasional, 2005.

Yaumi, Muhammad. Prinsip-prinsip Desain Pembelajaran. Cet. I, Jakarta: Kencana Pranada Media Group, 2013. 